\title{
A mitologia da noite e o sacerdote da lua em "Buriti" (Noites de sertão, 1965), de João Guimarães Rosa
}

\author{
Sarah Maria Forte Diogo \\ Doutoranda em Letras - Estudos Literários / UFMG
}

\begin{abstract}
RESUMO
Este ensaio analisa a trajetória do personagem Chefe Zequiel ("Buriti” Noites do sertão). Destacamos dois eixos interpretativos: o lugar social que o Chefe ocupa e sua relação com a noite. Nos delírios de Zequiel é possível ler a explicação mitológica do nascimento da noite e o prenúncio de novos tempos.
\end{abstract}

\section{PALAVRAS-CHAVE}

Culturas, João Guimarães Rosa, linguagem

A narrativa “Buriti”, constante em Noites do sertão (1965), apresenta várias frentes de leitura. Denominamos frentes de leitura os diferentes modos pelos quais o enredo pode ser narrado, conforme o ponto de vista assumido. Por ser uma novela polifônica, temos a narrativa perspectivada por diversos personagens. Para sintetizá-la, podemos sumariá-la desta forma: a estória das mudanças que ocorrem num local e em seus habitantes com a chegada de sujeitos exteriores a esse ambiente. A fazenda chama-se Buriti Bom, propriedade de Liodoro. Ele tem quatro filhos. Dos filhos, os mais referenciados são as duas mulheres, que representam comportamentos opostos: Maria da Glória e Maria Behú. Lalinha é abandonada pelo filho de Liodoro. Este vai para a cidade e traz a nora para a fazenda. A partir daí, Lalinha passa a interferir na vida dos demais personagens. No caso de "Buriti”, torna-se complicado falar em personagens secundários ou principais. Esse é um status instável na dinâmica dessa novela, pois um personagem secundário pode assumir as rédeas discursivas, tornando-se assim o principal.

Este ensaio pretende analisar a trajetória do personagem Chefe Zequiel da novela “Buriti”, constante em Noites do sertão, do escritor mineiro João Guimarães Rosa. Adotamos como método a pesquisa bibliográfica que, conforme Lakatos e Markoni, "não é mera repetição do que já foi dito ou escrito sobre certo assunto, mas propicia o exame de um tema 
sob novo enfoque ou abordagem, chegando a conclusões inovadoras”. ${ }^{1}$ Partilhamos também do método de exegese literária proposto por Antonio Candido, que, em muitos de seus escritos, afirma que: “(...) O alvo é analisar o comportamento ou o modo de ser que se manifestam dentro do texto, porque foram criados nele a partir da realidade exterior. (...) Importa no estudo da literatura o que o texto exprime”. ${ }^{2}$ Logo, como fundamentação teóricometodológica teremos a pesquisa de bibliografia sobre elementos que são recorrentes aos delírios do personagem - micronarrativas dentro da narrativa maior -, utilizando como fonte dicionários variados, o que caracteriza uma investigação dinâmica, pois a pesquisa não se confina a essa ação, em virtude de dialogar com a construção ficcional do escritor e os elementos nela inseridos. Para articular esse método ao estudo do texto partimos do conceito de Antonio Candido sobre obra literária:

Uma obra é uma realidade autônoma, cujo valor está na fórmula que obteve para plasmar elementos não-literários: impressões, paixões, idéias, fatos, acontecimentos, que são matéria-prima do ato criador. A sua importância quase nunca é devida à circunstância de exprimir um aspecto da realidade social ou individual, mas à maneira por que o faz. ${ }^{3}$

Como embasamento teórico, é possível aludir ao conceito de transculturação narrativa consoante Rama. Para ele, a transculturação é um processo de mediação ativo entre culturas, o que se manifesta nos textos de alguns prosadores latino-americanos, tanto na estrutura superficial - organização linguística - quanto na estrutura profunda - cosmovisão. Segundo Rama, Rosa seria um escritor transculturador, pois mediaria a relação entre duas ordens - a regional e a universal. ${ }^{4}$ Sobre Rosa, Rama diz:

[Rosa] parte de una lengua y de um sistema narrativo populares, hondamente enraizados em la vida sertaneja, lo que se intensifica com una investigación sistemática que explica la recolección de numerosos arcaísmos lexicales y el hallazgo de los variados puntos de vista com que el narrador elabora el texto interpretativo de una realidad, y se proyectan ambos niveles sobre un receptor-productor (Guimarães Rosa) que es un mediador entre dos orbes

\footnotetext{
${ }^{1}$ LAKATOS; MARCONI. Fundamentos da metodologia científica, p. 183.

${ }^{2}$ CANDIDO. Formação da literatura brasileira, p. 10-63.

${ }^{3}$ CANDIDO. Formação da literatura brasileira, p. 34.

${ }^{4}$ Salientamos a diferença fundamental entre os conceitos de transculturação para Fernando Ortiz e para Rama. Para Ortiz, a transculturação é o processo de trânsito de uma cultura para outra, porém, nesse trânsito, a cultura interior, local, regional perde para as influências externas. Já para Rama, que delineia outro conceito de transculturação, a cultura local é resistente e é a responsável por dar respostas criativas, o que torna o processo de transculturação como algo ativo, em que as culturas se relacionam e um mediador tenta articulá-las, não com base na ideia de perda, mas de criatividade. É o que Rama acredita que Guimarães Rosa faz em seus textos.
} 
culturales desconectadas: el interior-regional y el externo-universal.El principio mediador se introduce en la propia obra. ${ }^{5}$

Destacamos que não iremos neste ensaio detalhar a transculturação que ocorre nos textos, mas para examinar “Buriti”, é importante essa fundamentação teórica que considera o texto um objeto transculturado, pois veremos nessa novela justamente itens da cultura folclórica inseridos nos delírios de um personagem que não consegue digeri-los e, num esforço interpretativo, se expressa. A audiência interna da novela - demais personagens -, mergulhada numa cultura que já não se recorda de tantas alusões folclóricas, apenas ri e não entende, uma vez que não lhes atribui sentido. A mediação se dá dentro dos próprios delírios, que apontam para o mito do nascimento da noite. Há uma parcela da crítica rosiana que lê os relatos noturnos como tradução da noite ou mesmo como uma sinfonia, rumor profundo, melodia. ${ }^{6}$ Não desmerecemos essas críticas, porém, considerações dessa natureza obliteram ou não enxergam a coerência interna dos delírios e a possibilidade deles encenarem a reconstrução de um mito.

A fim de organizar nossa tarefa crítica, destacaremos dois eixos interpretativos: a condição social e econômica do Chefe na fazenda - lugar social que ocupa - e sua relação com a noite. Essa relação é verbalizada mediante delírios nos quais é possível ler a explicação mitológica para o nascimento da noite. Ressalte-se que o narrador em "Buriti" assume diversas configurações, colando-se aos personagens e verbalizando suas falas pelo discurso direto, indireto, indireto livre, predominando este último.

Chefe Zequiel cultiva lavoura de subsistência. Planta e colhe para seu uso. Não há referências sobre sua família - ascendentes ou descendentes - nem local de moradia fixa. $\mathrm{O}$ único pouso certo para Zequiel é o moinho: “O Chefe era baixote e risonho, quando respondia sabia fazer toda espécie de gestos. Risonho de sorriso, apesar de sua palidez. E ele muito se coçava."7 Seu modo de vida é assim sumariado:

(...) o Chefe plantava do que queria, o lucrozinho para si, e fechava sua roça no lugar que ele mesmo escolhesse. Mas transportava consigo, cada manhã, uns mantimentos, guardava latas e cabaças no ranchinho da roça, lá ele fazia questão de cozinhar seu almoço. Com isso, perdia tempo. E, de agora, por conta de abrir em claro as noites, de dia em vez de trabalhar ele vadiava,

\footnotetext{
${ }^{5}$ RAMA. Transculturación narrativa em América Latina, p. 54-55.

${ }^{6}$ É possível ler esse viés crítico em "Buriti: o ritual da vida”, de José Maurício Gomes de Almeida, p. 169-200.

${ }^{7}$ ROSA. Buriti, p. 172.
} 
deitava para se dormir, bôas horas. O que entendia era do oficio dos barulheiros do campo, quando que queremos ver visagens... ${ }^{8}$

Sobre o Chefe Zequiel, diz Guimarães Rosa em carta ao seu tradutor italiano: “E o Chefe Zequiel, um pobre-de-Cristo, semi-enlouquecida sua ignorância.”9 Mais um pobre-deCristo para a galeria rosiana. A figura de Zequiel nos lembra a de outra personagem, o velho Camilo. Ambos aportam nas estâncias vindos das entranhas do sertão. E ambos permanecem nas fazendas, porque não têm para onde ir. A condição de “desgarrados” desses personagens nos leva a refletir criticamente sobre o processo de urbanização brasileiro que deslocou, e ainda desloca, consideráveis contingentes populacionais que saem de seus locais de nascimento em busca de melhores condições de vida em centros maiores. Não encontrando essas condições e às vezes nem conseguindo chegar a centros mais desenvolvidos, iludem-se e tornam-se agregados domésticos em fazendas. Constituem uma parcela de sujeitos alijados dos centros de poder, mas que vivem à sombra desses mesmos centros e servindo como objeto de curiosidade geral. O lugar social que o chefe ocupa é esse: é periférico em relação à fazenda, é alvo de atenção dos outros por causar compaixão ou riso. Ignora-se sua história precedente porque ele é um ser cuja tradição particular esfacelou-se.

O velho Camilo é um pobre-de-Cristo, um ancião. Guarda ainda a aura de tempos passados, uma réstia de ensombrada honra. É respeitado por alguns. O mesmo não ocorre com o Chefe Zequiel: “É um Zequiel, Zequielzim - o Chefe... (...) ' - Que é que eu acho do Zequiel, o Chefe? Tolo na retoleima, inteiro. (...) Senhor verá: ele descreve tudo que diz que divulgou de noite - o senhor pedindo perguntando. Historêia muito. Eh, ele pinta o preto de branco... ."10 Nos fragmentos destacados, é possível observar que o Chefe é nuançado por Gualberto como um bobo, um tolo da fazenda. O uso do artigo indefinido e do diminutivo sugere inferiorização do sujeito, bem como a expressão “o Chefe” em itálico, seguida de reticências, exprime certa ironia em referenciá-lo assim. Alcunhado por Gual como tolo na retoleima, inteiro, o Chefe surge às vistas da maioria como um louco miserável, atordoado pela noite. Para Glorinha, Zequiel é uma curiosidade do lugar, o pitoresco sob forma humana: “(...) ela apresentava o Chefe como se ele fosse um talento da fazenda, com que o Buriti Bom pudesse contar - nos portais da noite, sentinela posta." ${ }^{11}$ Esse processo de tratar um ser

\footnotetext{
${ }^{8}$ ROSA. Buriti, p. 250.

${ }^{9}$ BIZZARRI. João Guimarães Rosa: Correspondência com seu tradutor italiano Edoardo Bizzarri, (1958-967), p. 104.

${ }^{10}$ ROSA. Buriti, p. 128-166.

${ }^{11}$ ROSA. Buriti, p. 233.
} 
humano como uma curiosidade sugere a destituição da substância do personagem. Ele passa a ser uma função. Suas palavras perdem-se, transformam-se em sinal de loucura, e não em índices problematizantes da realidade.

O nome de Zequiel pode ser associado ao profeta Ezequiel, um dos profetas maiores, sacerdote exilado em Babilônia, exercendo sua atividade entre os anos 593 a 571 a.C. No local de seu exílio, ele anuncia as sentenças divinas. Para Ezequiel, a sua comunidade será destruída, pois é uma sociedade corrupta e hipócrita, fadada, portanto, ao sofrimento. Apesar dessa negatividade, o futuro é de ressurreição. As descrições que surgem das palavras de Ezequiel são extremamente difíceis de imaginar, mas assustam pela grandiosidade das visões:

(...) "Criatura humana, obedeça ao que vou lhe dizer. Não seja rebelde como essa casa de rebeldes. Abra a boca e coma o que vou lhe falar.” Então notei que certa mão se estendia para mim com um rolo de pergaminho. A mão desenrolou o pergaminho diante de mim: estava escrito por dentro e por fora, e o que nele estava escrito eram lamentações, gemidos e gritos de dor. ${ }^{12}$

Javé coloca Ezequiel como uma sentinela, para advertir ao povo ignorante as intempéries que estão por vir. Engolindo um livro de lamentações, gemidos e gritos de dor, Ezequiel profetiza o que comera, como simples criatura humana diante da potência de Deus.

A associação entre Chefe Zequiel e o profeta Ezequiel por si só não significa um achado crítico deste ensaio. Lima, ${ }^{13}$ já se reporta a esse aspecto. O que é novo na ligação Zequiel e Ezequiel - é acreditarmos que exista um processo de releitura crítica da escritura bíblica que o autor instala como mecanismo de significação dentro do seu texto.

Temos em "Buriti” um Zequiel sem raízes, sem família, nominalmente marcado pela falta - é um Zequiel e não Ezequiel - que também engole um livro de sabedoria - a da noite mas não consegue anunciá-lo de modo compreensível a sua comunidade, pois se sente transtornado com ameaças imaginárias. É um profeta confuso, não tem explicação lógica para quase nada, o que também pode ser lido como crítica à religião entendida como modelo explicativo do mundo. É notável o medo de Zequiel da beata Maria Behú, que, com suas rezas, tenta preservar uma impossível pureza, representando assim a concepção de uma religião como alívio, paz, não como conflito. ${ }^{14}$

\footnotetext{
${ }^{12}$ BÍBLIA SAGRADA. Ez 2, 8-10.

${ }^{13}$ LIMA. O buriti entre os homens ou O exílio da utopia.

${ }^{14}$ Para ler sobre a personagem Maria Behú, conferir: DIOGO. Quando morre a flôr do sertão: figuração da morte em “Buriti” de João Guimarães Rosa, p. 214-228.
} 
O sertão é figurado como espaço que surpreende aquele que o adentra: “Quando se vem vindo sertão a dentro, a gente pensa que não vai encontrar coisa nenhuma." ${ }^{15}$ A gente pensa, mas, à medida que se vai adentrando, o sertão se revela em seus silêncios e sons. $\mathrm{O}$ Chefe Zequiel capta esses sons: “Aziago, o Chefe Zequiel espera um inimigo, que desconhece, escuta até aos fundos da noite, escuta as minhocas dentro da terra. Assunta, o que tem de observar, para ele a noite é um estudo terrível. (...) O que o Chefe devassou, assim, encheria livros.”16 Observe-se o termo empregado: devassar. Não está sob controle ter os delírios, mas mesmo assim ele “devassa” a noite.

O linguajar reticente do Chefe, o fato de acatar as pessoas pelos trajes, aceitar um sistema de trocas econômicas rudimentares, ao invés de comércio formalizado - há uma passagem em que ele dá palha em troca de fumo -, nos indica que o Chefe situa-se num estágio aquém da modernização. Ele encarna a sobrevivência e resistência de culturas arcaicas, porém é uma sobrevivência, ao ser vista pelo ângulo dos personagens que consideram Zequiel um tolo, desabilitando seu discurso, frustrada, uma vez que os delírios encenam também a impossibilidade de fazer-se entender para o outro mediante alusão a lendas e mitos: o próprio personagem tem medo, já não consegue extrair experiência transmissível da noite profunda. Ele extrai medos diversos. A razão de Zequiel desorganiza as informações da noite, pois não são lidas com os olhos do intelecto, mas com a visão de sentidos aguçados, à flor da pele.

Quando o Chefe se sente no auge de suas atribulações, procura riscar no chão um hexagrama. Esse sinal tem por função defender o ambiente de espíritos, proteger de influências malignas, e também de unir opostos. O Chefe utiliza o signo-salomão com a acepção de defesa: Quando a coisa piora de vir, eu rezo! E uma das ações integrantes dessa reza é a concretização, por meio do desenho, do selo de Salomão, amuleto contra a coisa. E o que seria essa coisa, passível de piorar? Seriam os sons da noite? Ou seriam os sons noturnos os arautos de possíveis infortúnios que se formam na escuridão do desconhecido?

A incompreensão dos outros - representados por Maria da Glória -, bem como o drama do Chefe em relação ao que ele não compreende não são de fácil entendimento:

Mas, não, Maria da Glória, por de demasiado perto o ter, mal o compreendesse, nem désse tino do constante agoniado padecer que o aprisionava. Bastava notar-se-lhe a descrença de olhos, o tom, o afadigado insistir com que ele, contando de tudo, como que procurava exprimir alguma

\footnotetext{
${ }^{15}$ ROSA. Buriti, p. 127.

${ }^{16}$ ROSA. Buriti, p.127.
} 
outra coisa, muito acima de seu poder de discernir e abarcar. Como se ele tivesse descoberto alguma matéria enorme de conteúdo e significação, e que não coubesse toda em sua fraca cabeça, e todas as inteiras noites não lhe bastassem para perseguir o entendimento daquilo. Ah, e o fato de resignarse, de não achar que os outros precisassem de compartilhar daquele medo tão grande. - “O Chefe todo-o-tempo tem dôr-de-cabeça. Não é, Chefe?” Tinha, sim, era verdade - ele sorria, grandes cantos da boca, seus olhos miravam miúdo. E tinha, entanto, a voz bôa e um jeito delicado, todo cumpridor de tudo, o respeito, seguindo sua vidazinha no bem-querer das obrigações. Trabalhava. Temia a noite, pontualmente, o pingo do barulho menor. Por isso, ao entardecer, vinha à cozinha, deixavam-no entrar no corpo da casa. Exultava quando havia rezas conjuntas - era um meio de diminuir o espaço da noite, o sozinho. Ajoelhado, era o mais obediente ao rangido das orações, não cochilava. Tudo terminado, ele ainda relutava em ir-se; e indagava sempre: - “Tem as indulgências?” Parecia querer um recibo, um papel, ou pensava que as indulgências fossem uma cédula de dinheiro. Ou, então, vinha ouvir música, quando punham a vitrola. Ficava a distância. ${ }^{17}$

A Igreja Católica Romana concedia as indulgências ao fiel, configurando-se estas uma espécie de passaporte para o Céu. ${ }^{18}$ No trecho, a voz do narrador informa que Zequiel trata algo abstrato como se fosse concreto, o mesmo procedimento que invade os delírios - tomar o abstrato como concreto -, não se filiando o personagem a um modelo de pensamento que abstrai conceitos da realidade. Ele não abstrai, não teoriza, o que pode caracterizá-lo como detentor de um pensamento arcaico, em conflito com influências externas.

A perseguição ao entendimento, a tentativa de devassar o transcendente, o incompreensível, fazem de Zequiel um escravo dos rumores noturnos. Sua fraca cabeça não suporta o peso da noite se fazendo. São muitas informações que chegam desencontradas a um pobre-de-deus, mas é esse pobre de Deus o escolhido para ser o chefe, o profeta. Leia-se: o profeta que não consuma seu papel, o que pode nos indicar que na ambiência histórica da novela - em que já se veem alusões a itens modernizantes, como o rádio que Glorinha escuta, o jeep de Miguel, as idas à cidade, os pertences citadinos de Lalinha - não há mais espaço para profetas, vistos como loucos.

O processo de adoecimento de Maria Behú parece iniciar-se simultaneamente ao processo de movimentação dos personagens: é a partir da sua doença, do estágio pré-morte, que podemos observar a narrativa cedendo a certos movimentos: os encontros noturnos entre Liodoro e Lalinha iniciam-se, e Glorinha entrega-se a Gualberto. É também época de ressurreição para Zequiel.

${ }^{17}$ ROSA. Buriti, p. 233-234.

${ }^{18}$ De acordo com Mário Ferreira dos Santos: “(...) Na Teologia, [a indulgência] é a remissão das penas dos pecados, concedida pela Igreja, em virtude dos méritos superabundantes do Salvador" (SANTOS. Dicionário de filosofia e ciências culturais, p. 785-786). 
Behú adoece no período posterior à Semana Santa:

Fazia tempo que cessara a cerração de águas. O tempo era claro, balançavase o vir do frio. A camélia plantada por mão de Lalinha deu flôr. Honrou-se o aniversário de Behú, e o de iô Liodoro, festejaram-se tão simples como sempre, tomava-se vinho-do-porto e do de buriti, perfumoso vinho óleo. As primeiras boiadas engordadas se enviaram. Mataram, rio adiante, duas onças-pretas. Passou-se a Semana-Santa. E no entanto Maria Behú adoecera. $^{19}$

As marcas temporais são balizadas por acontecimentos que seguem a diç̧ão da natureza: “A camélia plantada por mão de Lalinha deu flôr”, "Mataram rio adentro duas onças-pretas”. Os habitantes do Buriti Bom não obedecem a uma cronologia determinada e estabelecida. O tempo passa ao ritmo de acontecimentos cotidianos e naturais. O período em que Behú adoece não pode ser olvidado: após a Semana Santa. Para o Cristianismo, é durante a Semana Santa que Jesus Cristo sofre, é crucificado, sepultado e ressuscita. É o seu calvário. A Igreja medita sobre o sofrimento de Cristo, sua ressurreição à Páscoa. Behú adoece após essa data, ou seja, perto da Páscoa. A menção ao tempo posterior a essa emblemática semana nos sugere que a via crucis de Behú inicia-se contra o esperado: num tempo de ressurreição, Behú principia a morrer: “E no entanto Maria Behú adoecera.” Porém, a Páscoa é também libertação.

Num período de ressurreição, observamos o maturar da morte em Behú. O comportamento da enferma é assim descrito: "Maria Behú não tinha uma queixa. Ela queria sua saúde, devagar, e queria o bem de todos; a fim de animar e de um modo ajudar, pedia notícia de tudo na casa."20

Tal comportamento fornece ao narrador margem para a seguinte indagação: “Agradeceria a Deus os seus sofrimentos?”, ${ }^{21}$ que logo é respondida: “Agradecia-lhe ter-lhe conservado o sono calmo.”22 Tal resposta alude ao caráter brando da personagem, à maneira de um animal imolado em sacrifício. Observemos no trecho destacado os vocábulos e expressões selecionados para descrever-lhe o comportamento: “não tinha uma queixa”; “devagar”; “queria o bem de todos”; “animar” e “ajudar”.

Simultaneamente à doença de Behú, temos uma moléstia nervosa e física que acomete o Chefe. Observemos que a ordem habitual vai sendo paulatinamente revertida com as

\footnotetext{
${ }^{19}$ ROSA. Buriti, p. 264-265.

${ }^{20}$ ROSA. Buriti, p. 265.

${ }^{21}$ ROSA. Buriti, p. 265.

${ }^{22}$ ROSA. Buriti, p. 265.
} 
preliminares da morte da beata: o Chefe, que outrora comunicava seus terrores, já não narra mais os pesadelos que durante a noite o assaltavam. Ao passo que Behú adoece, Zequiel manifesta mudanças, seu estado agrava-se.

Os medos do Chefe, se antes eram inclinados ao pavor de uma morte encomendada, um sorrateiro assassinato, agora vibram nesta direção: “A não, ele tinha declarado confissão de dizer: que eram só no adejo uma mãos, que dava idéia - pensamento dumas roxas mãos, que por estrangulação rodeavam.”23

Mãos que estrangulam, matizadas pela litúrgica cor do roxo. Maria Behú, constantemente coberta de escuras vestimentas, em especial o roxo, evoca a imagem da morte, que, para o Chefe, é “estrangulação”, perigo que ataca à revelia da vítima, nos esconsos da madrugada.

O medo do Chefe, antes da morte de Behú, tem como centro a forma fantasmagórica e ameaçadora de uma mulher, metamorfoseada em coisa:

Denegrim, manso e manso, a coisa. Doem as costas do Chefe, a partir dos ombros. De da testa, e em baixo no pescoço, esfriam dedadas de suor, que olêia. O pior, é que todo dia tem sua noite, todo dia. Evém, vem: é a coisa. A môrma. Mulher que pariu uma coruja. Cachorro desperta e renova latido de outro cachorro longe, eles levam notícia errada a uma distância enorme. Homem quiser dormir, é como ter vertigem. Essa que revém, em volta, é a môrma. Sobe no vaporoso. - Desconjuro! Tem formas de barulhos que ninguém nunca ouviu, não se sabe relatar. O Chefe guarda todos eles na cabeça, conforme não quis. Não quis, até aos respingos do campo, até aos galos, no pintar da aurora. ${ }^{24}$

A dicção narrativa assume ritmo de suspense para o detalhamento da Môrma: Denegrim, manso e manso, a coisa. O sofrimento físico do Chefe é sumariado: dor nas costas, suor abundante. As preliminares do terror. Evém, vem: uma forma de saudação. A môrma. Mulher fantasma, possivelmente fecundada por um monstro, pois que parira um bicho agourento: uma coruja. Acerca da môrma, Guimarães Rosa informa em correspondência com seu tradutor italiano que a Môrma é um ser formado pelos pensamentos das pessoas enquanto elas dormem, é uma máscara assustadora, uma projeção dos sonhos de todas as pessoas.

A Môrma se forma durante o sono dos outros. É construída a partir das exalações ou projeções anímicas. É, portanto, o que de pior há em cada ser. Perguntado acerca da caracterização da coisa, o Chefe responde: “Como era o 'inimigo’, ô Chefe? - 'Vai ver, é uma coisa, que não é coisa. Roda por aí tudo. Se a gente dormindo, ela tira as forças da gente...

\footnotetext{
${ }^{23}$ ROSA. Buriti, p. 266.

${ }^{24}$ ROSA. Buriti, p. 186-187.
} 
Vem, mata. É uma coisa muito ligeira esvoaçada, e que não fala, mas com voz de criatura....”. ${ }^{25}$ Uma coisa, que não é coisa, que não fala, mas tem voz de criatura: a Môrma é construída verbalmente por meio de antíteses: som e silêncio, presença e ausência, forma disforme.

Behú liga-se ao Chefe porque ambos palmilham o transcendente. Ela, mediante um sistema estabelecido de rezas e penitências, com um Deus definido a quem recorrer. Behú manifesta a relação com o sagrado até no olhar que lança à natureza: o Buriti parece uma catedral. O sagrado que ela almeja espraia-se pelo ambiente. Já o Chefe Zequiel apalpa o transcendente pela via do medo e das profecias que o ultrapassam. Ele julga que o vento igreja $^{26}$ as árvores, ou seja, varre o céu diligentemente, no respeitoso e grave compasso de medo que uma igreja inspira.

Zequiel engoliu o livro da sabedoria, mas não tem um Deus passível de conduzi-lo. Está perdido na construção da noite profunda. O medo que sente por Behú afigura-se como pavor da punição de um deus onipotente e também crítica a existência de um Deus que organize tudo, pois “quem tem ouvidos que ouça o que o Espírito diz às igrejas...” Apesar dela nutrir por ele cuidados fraternais, sua figura de beata é posta sob suspeição, pois ela é representante de um sagrado que, para Zequiel, é ameaçador. Por isso ele melhora quando ela falece. Ele e sua comunidade estão a salvo. Se aquela que desempenhava a função de protetora espiritual da fazenda morreu, então é porque o Buriti Bom não necessita mais de proteção, nem há mais o que temer.

As figuras recorrentes aos delírios do Chefe são a coruja, o urutau, o sapo, a lua, a cobra-grande e os macaquinhos. Sobre a coruja, Manfred Lurker explica:

(lat. noctua, de noctu $=$ noite), ligada ao reino das trevas e da morte. $\mathrm{Na}$ índia, ave dos mortos; também na Arábia e na Etiópia surgem como corujas as almas dos mortos. A coruja desfrutava honras divinas em Pylos. Na língua alemã popular, também denominada de "galinha dos cadáveres." É considerada animal dos fantasmas, ave das bruxas (...) e provavelmente deve ser compreendida como animal demoníaco também na escultura arquitetônica românica. Em outras representações de conteúdo cristão, sinal da descrença e de vícios (sobretudo volúpia e preguiça); no tema da crucificação indica os que estão sentados à sombra da morte aos quais o Salvador traz a luz. Na Grécia, a coruja era consagrada a Palas, Atena, a deusa de todas as atividades científicas, tornando-se, daí, símbolo da

${ }^{25}$ ROSA. Buriti, p. 169.

26 “O vento úa, morrentemente, avuve, é uma oada - ele igreja as árvores” (ROSA. Buriti, p. 187.) É a descrição dos sons que povoam a noite, mediante observação do narrador acerca dos delírios do Chefe Zequiel. Esse discurso é reportado pelo narrador, mas, por vezes, mistura-se à voz do personagem, de modo que não é possível, nem operacional, separá-los 
Sabedoria. Segundo Paulino de Nola (morto em 431), a coruja é observadora da luz do mundo também nas trevas. ${ }^{27}$

Câmara Cascudo, ao inventariar as superstições em torno da coruja, confirma o que é de conhecimento do imaginário popular: a crença na má sorte que esse bicho traz. É interessante a reiterada presença desse animal na maioria dos delírios do Chefe, o que reforça o mau pressentimento que habita seus pesadelos. Sobre o sapo, Cascudo aponta que é um animal muito utilizado na feitiçaria, pelas bruxas: "É um elemento indispensável nas bruxarias, servindo de paciente para a transmissão mágica do feitiço. O sapo é um personagem vivo em todas as literaturas orais do mundo.”28 Acerca do Quibungo, que aparece em um dos delírios, o estudioso aponta sua procedência na literatura oral africana, como o monstro que comia crianças. Há também a referência à Cuca: "Onde agora, é o miolo maior, trevas. Horas almas. A coruja, cuca. O silencio se desespumava. A coruja conclúi.”29 Sobre a Cuca, Cascudo informa:

Papão feminino, fantasma informe, ente vago, ameaçador, devorando as crianças, papona. Amadeu Amaral (O Dialeto Caipira, São Paulo, 1920): Entidade fantástica com que se mete mêdo às criancinhas. (...) A COCA e a CUCA são sinônimos de pavores ou de paponas insaciáveis. CUCA é avô em nbundo e o trago, que se engole de uma vez, no idioma tupi. Assim, os elementos indígenas e africanos concorrem para a dispersão do mito nos elementos característicos. Cuca, ensina Teodoro Sampaio, é uma coruja. ${ }^{30}$

O urutau e o noitibó, aves noturnas, entram em cena, sobrevoando os delírios e injetando medo à tessitura das palavras:

(...) Agora, recomeçam os sapos: eles formam dois bandos. Lua defeita, o silêncio se afunda, afunda - o silêncio se mexe, se faz. O urutáu, que o canto dele encantado de gente, copiando: é um homem ou mulher, que estão sendo matados, queixas extremas. (...) - Nhanão, iàssim... Quero ver as três corujas?! Os sapos se interrompem de súbito: seu coro de cantos se despenhou numa cachoeira. No silêncio nunca há silêncio. Se assoviaram e insultaram os macacos, se abraçam com frio. Tiniram dentes. Reto vôa o noitibó, e pousa. O urutáu-pequeno, olhos de enxofre. ${ }^{31}$

Em Câmara Cascudo, encontramos as seguintes informações sobre o urutáu:

\footnotetext{
${ }^{27}$ LURKER. Dicionário de simbologia, p. 158.

${ }^{28}$ CASCUDO. Dicionário de folclore brasileiro, v. 1, p. 591.

${ }^{29}$ ROSA. Buriti, p. 187.

${ }^{30}$ CASCUDO. Dicionário de folclore brasileiro, v. 1, p. 510.

${ }^{31}$ ROSA. Buriti, p. 155-179.
} 
Ainda a Lua, urutau, jurutau (Caprimulgidae), do gênero Nyctibios, comum à América do Sul. Ave noturna, seu canto melancólico e estranho, lembrando uma gargalhada de dor, cercou-a de misterioso prestígio assombrador. Está rodeada de lendas e superstições, espavorindo a gente do campo, personalizando fantasmas e visagens pavorosas. Só quem haja ouvido o grito da mãe-da-lua pode medir a impressão sinistra e desesperada que êle provoca durante a noite. A jurutauí, um pouco menor, mas também chamada mãe-da-lua (Nyctibius jamaicensis), tem aplicação curiosa contra a sedução sexual: "A pele da ave noctívaga jurutauí preserva as donzelas e as faltas desonestas. Conta-se que antigamente matavam para isso uma destas aves e tiravam a pele que, sêca ao sol, servia para nela assentarem as filhas, justamente nos três primeiros dias do início da puberdade. Parece que esta posição era guardada por três dias, durantes os quais as matronas da família vinham saudar a moça, aconselhando-a a ser honesta. No fim dêsses dias, a donzela saía curada, isto é, invulnerável à tentação das paixões desonestas, a que seu temperamento, destarte modificado, a pudesse atrair (CENAS DA VIDA AMAZÔNICA,62, Lisboa, 1886). Veríssimo adianta que êsse cerimonial fôra abolido e que se limitavam a varrer o chão sob a rêde da moça com as penas de urutauí ou jurutauí. A guarani Nheambú transformouse em urutau, por ter morrido seu amado Quimbae; noutra lenda (do rio Araguaia, entre os Carajás) Imaeró se mudou nessa ave, porque Tainá-Can (estrêla-d'alva) preferiu sua irmã Denaquê para espôsa. ${ }^{32}$

O urutáu-pequeno, antigamente, conforme registra Cascudo, era utilizado como meio de coibir o desejo feminino, para que a moça não fosse arrastada por paixões sensuais. Também alcunhada de mãe-da-lua, nome atribuído possivelmente em função do enigmático canto desta ave e dos supostos poderes da lua em reger o humor das pessoas, a inserção dessa ave na narrativa não se dá somente pelo fato de o Chefe sumariar os sons da noite, mas porque esse animal é tão, ou mais, agourento que a coruja, pois "Só quem haja ouvido o grito da mãeda-lua pode medir a impressão sinistra e desesperada que êle provoca durante a noite” e também porque ele personifica fantasmas. E qual é o pavor do Chefe? A ideia de um vulto, uma visagem, uma coisa que vem para trucidá-lo à revelia, cujos avisos surgem nos detalhes da noite:

O mato abanado. - Zequiel, você foi ouvir, agora teme! Visonha vã, é quem vem, se acerca do moinho, para não existir. Tagoaíba. O mau espírito da parte de Deus, que vem contra. Tudo o Chefe não sabe, amarrado ao horror. A anta ri assoviando. Atrás, em cada canto do campo, tem uma cobra, espreitante. O vento muda: traz voz, marmúgem. (...) O Chefe, não; não se concede. Se descuidar, um segundo, um está ali, ao pé dele, dentro dele. Não se tem porta, para esse, para se fechar. Tramela nem cadeado! Esfria, afria, o que é da noite - toalhados de frio. O inimigo não vem. Só se um cachorro avisar, só se um cachorro uivar uivos.

(...) O Chefe Zequiel:

- "Mesmo muito antes do primeiro galo em-cantar, que foi, um cão uivou no terreirinho do José Abel...” O Chefe, ele escuta, de escarafuncho. Trás noite,

${ }^{32}$ CASCUDO. Dicionário de folclore brasileiro, v. 2, p. 128. 
trás noite, o mundo perdeu suas paredes. Fere um grilo, serrazim. Silêncio. E os insetos são milhões. O mato - vozinha mansa - aeiouva. Do outro mato, e dos buritis, os respondidos. Mais frio e cheio de calor, o Brejão bole. Um peixe espiririca. (...) Se a pausa é maior, as formigas picam folhas; e as formigas que moram em árvores. - Ih!... Os duendes são tantos, deles o Chefe não tem medo. Teme a inimiga - uma só. O toque de lata é de um boi ladrão, tangendo seu polaco. $\mathrm{O}$ vento muda é para se benzer em cruz. $\mathrm{O}$ rouquejo forte que os jacarés gostam de gritar, repeitido. Esfriou mais, os jacarés para o meio do rio retombam, onde as águas rolam mornas. Maior é a mata, suas entranhas, onde os bichos têm seu caminho de ofício, caminhos que eles estudaram de tudo; o tênue assopro com que eles farejam. Uma coruja miou, gosmenta. A coruja quer colóquio. Sapos se jogam de sua velha pele. Esses são feiticeiros. Sempre que há um desgosto muito fundo, há depois um grande perigo... Deu tumbo. Nos Gerais, o vento arranca as árvores agarradas pelos cabelos. O chão conserva meses o gurgo das trovoadas. As irmãzinhas estão dormindo. Se a onça urrar, no mato do Mutúm, todos da casa acordarão dando pranto, é preciso botar os cachorros para dentro, temperar comida para os caçadores... Um homem com a espingarda, homem de cara chata, dôido de ruivo, no meio da sala, contando casos de outras onças, que ele matou. Tinha as botas até quase no meio da coxa, e de entradas alargadas. (...) Ninguém, nessa madrugada, não tinha medo desse homem... Há um silêncio, mas que muito roem, ele se desgasta pelas beiras, como laje de gelo. (...) Cada um escuta separado o que quer. A pessôa que vem vindo, não me dá pestanas. As irmãzinhas estão dormindo... Vão matar o Quibungo... E tem uma cachorrinha, latindo, de lá do Céu - Quem tapa a noite é a madrugada. ${ }^{33}$

O trecho inicia-se com a caracterização geral do mato: “o mato abanado”. Uma voz, representada em itálico, ecoa: Zequiel, você foi ouvir, agora teme! A seguir, há a inserção da Môrma - visonha vã. Ela se aproxima, paradoxalmente para não existir, o que a torna bem mais assustadora. O vocábulo Togoaíba, do tupi, indica a natureza dessa "visagem”: é um mau espírito da parte de Deus, que vem contra. Quem vem contra? O mau espírito ou Deus? Após a caracterização do estado alerta do chefe, do fato de ele não poder descuidar, temos os sons da noite, organizados numa progressão: dos mais gerais - como o som do vento - aos mais específicos - como o som das formigas picando folhas:

E os insetos são milhões. O mato - vozinha mansa - aeiouva. Do outro mato, e dos buritis, os respondidos. Mais frio e cheio de calor, o Brejão bole. Um peixe espiririca. (...) Se a pausa é maior, as formigas picam folhas; e as formigas que moram em árvores. - Ih!... Os duendes são tantos, deles o Chefe não tem medo. Teme a inimiga - uma só. O toque de lata é de um boi ladrão, tangendo seu polaco. $\mathrm{O}$ vento muda é para se benzer em cruz. $\mathrm{O}$ rouquejo forte que os jacarés gostam de gritar, repeitido. Esfriou mais, os jacarés para o meio do rio retombam, onde as águas rolam mornas. Maior é a

\footnotetext{
${ }^{33}$ ROSA. Buriti, p. 155-179.
} 
mata, suas entranhas, onde os bichos têm seu caminho de ofício, caminhos que eles estudaram de tudo $(. . .)^{34}$

Escutando de modo escarafunchado, entranhando-se na terra, noite após noite, o chefe escuta. Escuta a tal ponto que o mundo, durante o dia entre paredes, surge noturno e devassado, pois que perdeu as travas que o isolavam da natureza.

A passagem que figura em itálico parece uma estória:

Sempre que há um desgosto muito fundo, há depois um grande perigo... Deu tumbo. Nos Gerais, o vento arranca as árvores agarradas pelos cabelos. O chão conserva meses o gurgo das trovoadas. As irmãzinhas estão dormindo. Se a onça urrar, no mato do Mutúm, todos da casa acordarão dando pranto, é preciso botar os cachorros para dentro, temperar comida para os caçadores... Um homem com a espingarda, homem de cara chata, dôido de ruivo, no meio da sala, contando casos de outras onças, que ele matou. Tinha as botas até quase no meio da coxa, e de entradas alargadas. (...) Ninguém, nessa madrugada, não tinha medo desse homem. ${ }^{35}$

O trecho narra uma noite de grande medo, pois onças rondavam na mata. Um homem ruivo então é convocado, para exterminar os bichos. É um onceiro: "Ninguém, nessa madrugada, não tinha medo desse homem...” Nessa madrugada, ninguém temia o onceiro, mas e depois? O trecho nos lembra a estória do "Meu tio, O Iauretê”, o onceiro indígena que passa a caçar humanos. Para o fragmento em itálico, vemos lapsos da estória de menino Miguilim: irmãzinhas dormindo no Mútum, lugar do Miguilim, uma cachorrinha latindo do céu - a pingo de ouro, que morre em Campo geral.

O Quibungo, papão que come criancinhas, pertence à literatura oral africana. É impossível ignorar tantas referências culturais: são referências literárias internas, entre obras do próprio escritor; folclóricas - com inserção de figuras africanas e indígenas. Até duendes entram no delírio. A coerência interna dessas passagens está no fato de haver articulação entre essas referências, elas se relacionam dinamicamente para compor o painel da noite. Não estão soltas, como se pode imaginar numa primeira leitura, nem são mera reconstituição estilística do período noturno. Elas contam modernamente como um personagem arcaico lê a noite e como ele entra em conflito com sua aparente fragmentação.

Zequiel também detém o poder de manipular enunciações aforísticas, proverbiais. Porém, seja pelo contexto, seja pela situação da personagem na narrativa, as expressões aforísticas do chefe têm lastro transcendental, não divisado nos aforismos de Gualberto:

\footnotetext{
${ }^{34}$ ROSA. Buriti, p. 179.

${ }^{35}$ ROSA. Buriti, p. 179.
} 
O vento muda é para se benzer em cruz. (...) Maior é a mata, suas entranhas, onde os bichos têm seu caminho de ofício, caminhos que eles estudaram de tudo; o tênue assopro com que eles farejam. (...) Sempre que há um desgosto muito fundo, há depois um grande perigo... (...) O chão conserva meses o gurgo das trovoadas (...) Cada um escuta separado o que quer. (...) Quem tapa a noite é a madrugada. ${ }^{36}$

A primeira frase constitui um aforismo de explicação de um fenômeno natural - os meneios que o vento faz é porque ele está se benzendo. A segunda oração, "Maior é a mata (...)”, parece explicar que a mata onde os bichos labutam - caçam, acasalam-se, fogem - é a mata mais densa, mais importante, por extensão: o local onde o homem dorme, repousa, não é o espaço de destaque. A estância relevante é onde ele exerce seus ofícios. A primeira frase em itálico é um pensamento popular, uma crença: quando algo ruim ocorre, deve-se rezar para que outros acontecimentos ainda mais nefandos não ocorram. A segunda, em itálico, pode ser lida como a memória da terra e, por extensão, das pessoas: após um abalo, trovoadas, o gurgo - ressonância - permanece. O ato de cada um escutar "separado o que quer" tem matriz bíblica no Apocalipse de São João: “Quem tem ouvidos que ouça o que o Espírito diz às igrejas... . "37 E a última frase de nosso elenco é um aviso: somente quem pode parar a noite é a madrugada, prenúncio de que o dia se iniciará: “Depois, tanto silêncio no meio dos rumores, as coisas todas estão com medo. Então, o que vem, é uma cobra desconforme, cor de olhos. Calamidade de cobra. Um mau espírito, ainda sem nenhuma terra.”38

O medo derrama-se sobre o ambiente, contaminando as coisas. O que vem, num primeiro momento, não é uma coisa, uma mulher, mas sim uma desconforme cobra a avançar nos meandros da noite: uma calamidade de cobra, um espírito pecador para o qual somente restou a forma réptil, rastejante. Em outro trecho temos que: “Os macaquinhos gritam, gritam, não é bem de frio - dansam ao redor de um trem nú. Cobra-Grande Comeu um deles. Sucurí chega vem dentro de roça. Um macaco pulava num pé só, sacudia no ar uma perna tesa dura de frio, entanguida, ele assim parecia até um senhor.”39

A noite, filha do Caos, é uma das divindades mais antigas citadas por Hesíodo, na Teogonia. A lenda da cobra-grande perpassa os delírios do chefe Zequiel, de modo difuso, mas dentre as alusões podemos identificar como cerne o nascimento da noite. Ao longo do

\footnotetext{
${ }^{36}$ ROSA. Buriti, p.179.

${ }^{37}$ Apocalipse de São João, (BÍBLIA SAGRADA. 2:7,11,17,29; 3:6, 13, 22) No conto "Curtamão" (Tutaméia, 2001), temos: "Mulher, o que quer, ouve, tão mal, tão bem; todo-o-mundo neste mundo é mensageiro" (ROSA. Curtamão, p. 70).

${ }^{38}$ ROSA. Buriti, p. 155.

${ }^{39}$ ROSA. Buriti, p. 179-180.
} 
tempo, a lenda fragmentou-se, tornando-se impossível reconstituir-lhe as feições originais. No Dicionário de Folclore Brasileiro, temos que:

Uma moça engravidara da coisa-má, maá-aiua, ou bebendo um ôvo de mutum, onde havia um cabelo humano, tendo uma grande cobra por filho, seguindo-a por tôda parte. A mulher conseguiu esconder-se; a cobra procurou-a, chamando-a, no fundo do rio e pela mata, e, desiludida, voou para o céu, onde se transformou em estrêlas. (...) Couto de Magalhães ouviu a lenda Mai Pituna o uquan ãna, como a noite apareceu nela, numa época em que não havia noite, a filha da Cobra-Grande, Boia-Uaçu menbira, casou e pediu ao pai, rubra, a noite. A Cobra-Grande mandou a noite dentro de um caroço de tucumã (Astrocarynum tucumã, Mart). Senhora dos elementos, a Cobra-Grande tinha os poderes cosmogônicos, e o conto, da classe dos etiológicos, explica a origem de animais, aves, peixes, o dia e a noite. Êsse mito desapareceu em sua compreensão popular e já na primeira metade do século XIX estava disperso e confuso. ${ }^{40}$

Em "Buriti”, a Môrma é a mulher que pariu uma coruja, bicho agourento, que singra os céus da narrativa, amortalhando a noite com seu canto. "Buriti” procede à reconstrução da lenda da cobra-grande. Vimos o destaque dados aos macaquinhos “Os macaquinhos gritam, gritam, não é bem de frio - dansam ao redor de um trem nu” e a atuação da cobra-grande, que devora um deles. As imagens dos delírios de Zequiel soam ininteligíveis, porém, ao conhecermos pedaços da lendária narrativa, observamos que João Guimarães Rosa incrustou, às delirantes palavras de sua personagem, partes de uma lenda praticamente esquecida, conforme atesta Câmara Cascudo. Essa integração da lenda à narrativa constitui uma nova leitura da lenda, bem como à concepção mítica de estar no mundo. Esta releitura da lenda do nascimento da noite a partir dos delírios do Chefe retoma o projeto modernista de interpretação dos mitos nas culturas do Brasil. ${ }^{41}$

Em “Buriti”, um dos macaquinhos é devorado pela cobra-grande. A cobra, portanto, devora a própria filha, ou seja, devora parte de si, parte de seu corpo, fechando assim um círculo: a mãe que devora a filha volta a sua própria descendência, retornando às origens. Lemos criticamente esse ponto como a sugestão da serpente uroboro, símbolo da união entre opostos.

\footnotetext{
${ }^{40}$ CASCUDO. Dicionário de folclore brasileiro, v. 1, p. 452.

41 "Macunaíma tremeu assustado espantou os mosquitos e caiu no pajuari por demais pra ver si espantava o medo também. Bebeu e dormiu noite inteira. Então chegou a Cobra Preta e tanto que chupou o único peito vivo de Ci que não deixou nem o apojo. E como Jiguê não conseguira moçar nenhuma das icamiabas o curumim sem ama chupou o peito da mãe no outro dia, chupou mais, deu um suspiro envenenado e morreu.” (ANDRADE. Macunaíma: o herói sem nenhum caráter, p. 22).
} 
A uroboro nos remete ao símbolo do infinito, a lemniscata: “[Do lat. lemniscata, 'ornada de fitas', a sua forma, um 8, lembra um laço de fitas.] S.f. Geom. Lugar geométrico dos pontos de um plano cujas distâncias a dois pontos fixos desse plano são constantes.”42 $\mathrm{O}$ autor utiliza essa representação do infinito ao final de Grande sertão: veredas e no índice de Primeiras estórias. O trem nu em torno do qual dançam os macaquinhos poderia ser o caroço de tucumã violado, despido de sua segurança que aprisionava as trevas, de onde brotara toda a noite e sua força sonora.

Concluímos este artigo retomando o conceito de transculturação adotado e observamos que os delírios, se elucidados, fazem uma mediação entre as culturas internas, regionais, da América Latina, conforme constatamos com a pesquisa de alguns termos, a fim de reconstruir um mito. Observou-se que chefe Zequiel foi o receptor confuso dessas referências e que Guimarães Rosa, enquanto transculturador, em vez de organizá-las num texto transparente, opta pela solução estética de reconstruí-las num discurso delirante, mantendo, desse modo, seus significados que ganham força diante da incompreensão, pois se reforçam no seio do sistema de referências multiculturais que o escritor concebe.

A incompreensão do próprio personagem da narrativa, que sente medo, e a leitura de alguns críticos, que simplesmente optam por não analisar os delírios, adotando fórmulas de leitura simplistas, não invalidam nossa interpretação e os resultados alcançados, que são três: a) os delírios do Chefe constituem um caldeirão cultural, integrando em seu magma linguístico termos do tupi, expressões aforísticas, onomatopeias, crendices, figuras do folclore africano, animais da nossa fauna imantados de agouro campestre; b) os delírios são um laboratório de experimentação verbal enunciados, ora por um narrador maestro, que rege sutilmente o suposto caos, ora enunciado por uma personagem profeta, que narra da noite e de seus percalços; e por fim c) os delírios concretizam uma forma de resistência, permanência e criatividade de culturas e tradições internas, pois mesmo que os demais não compreendam o que o chefe percebe, ele continua com os delírios, curando-se apenas quando a representante da cultura religiosa tradicional - Maria Behú -, aquela que enxergava o sagrado e temia o profano, falece.

\footnotetext{
${ }^{42}$ FERREIRA. Novo Dicionário de língua portuguesa, 1986, p. 1.020.
} 


\section{ABSTRACT}

This essay examines the trajectory of the character Chef Zequiel ("Buriti”Nights of the interior). Featuring two axes of interpretation: the social place that occupies the head and its relationship with the night. In delusions of Zequiel you can read the mythological explanation of the birth of the night and the harbinger of new times.

\section{KEYWORDS}

Cultures, João Guimarães Rosa, language

\section{REFERÊNCIAS}

ALMEIDA, José Maurício Gomes de. Buriti: o ritual da vida. Revista Metamorfoses, Rio de Janeiro, v. 2, p. 169-200, 2001.

ANDRADE, Mário de. Macunaíma: o herói sem nenhum caráter. Belo Horizonte: Villa Rica Editoras Reunidas, 1990.

BÍBLIA SAGRADA. 7.ed. Trad. CNBB. São Paulo: Canção Nova, 2008.

BIZZARRI, Edoardo. João Guimarães Rosa: correspondência com seu tradutor italiano Edoardo Bizzarri. (1958-967). Rio de Janeiro: Nova Fronteira, 2003.

CANDIDO. Formação da literatura brasileira: momentos decisivos. 5. ed. Belo Horizonte: Itatiaia; São Paulo: Edusp, 1975. v. 1.

CASCUDO, Luís da Câmara. Dicionário do folclore brasileiro. Rio de Janeiro: Brasileira de Ouro, 1960. 2 v.

DIOGO, Sarah Maria Forte. Quando morre a flôr do sertão: figuração da morte em "Buriti” de João Guimarães Rosa. Scripta, Belo Horizonte, v. 13, p. 214-228, 2008.

FERREIRA, Aurélio Buarque de Holanda. Novo Dicionário de língua portuguesa. 2. ed. rev. e aum. Nova Fronteira: Rio de Janeiro, 1986.

LAKATOS, Eva Maria; MARCONI, Marina de Andrade. Fundamentos da metodologia científica. 3. ed. São Paulo: Atlas, 1991.

LIMA, Luís Costa. O buriti entre os homens ou O exílio da utopia. In: LIMA, Luís Costa. A metamorfose do silêncio. Rio de Janeiro: Eldorado, 1974. p. 129-186.

LURKER, Manfred. Dicionário de simbologia. 2. ed. Trad. Mario Krauss et al. São Paulo: Martins Fontes, 2003.

RAMA. Transculturación narrativa em América Latina. 2. ed. Buenos Aires: Ediciones El Andariego, 2008.

ROSA, João Guimarães. Buriti. In: ROSA, João Guimarães. Noites do sertão. 9. ed. Rio de Janeiro: Nova Fronteira, 2001. p. 117-316.

ROSA, João Guimarães. Curtamão. In: Tutaméia: terceiras estórias. 8. ed. Rio de Janeiro: Nova Fronteira, 2001. [0]p. 67-71. 
SANTOS, Mário Ferreira dos. Dicionário de filosofia e ciências culturais. São Paulo: Matese, 1963. v. 3. 